\title{
The Effect of Piano Education on Visual Memory
}

\author{
Elnara Recepli ${ }^{1} \&$ Hatice Onuray Eğilmez ${ }^{1}$ \\ ${ }^{1}$ Music Education Department, Bursa Uludağ University, Bursa, Turkey \\ Correspondence: Hatice Onuray Eğilmez, Music Education Department, Bursa Uludağ University, Bursa, 16059, \\ Turkey.
}

Received: September 19, 2021

doi:10.5539/ies.v15n1p87
Accepted: November 14, $2021 \quad$ Online Published: January 19, 2022

URL: https://doi.org/10.5539/ies.v15n1p87

\begin{abstract}
In this research, the aim is to determine the effect of piano education on visual memory. One of the quantitative research methods, experimental research design, was used in the study, and the study group was determined with the purposive sampling method. The short-term visual memory of the students aged from 8 to 12 (experimental $\mathrm{n}=36$, control $\mathrm{n}=42$ ) in the study group was measured with the Benton Visual Retention Test F Form. To determine the effect of the practice for the experimental and control groups, t-tests and two-way analysis of variance (mixed-design ANOVA) were performed for the pretest and posttest. The short-term visual retention test pre-test and post-test results of the experimental group students who took private piano lessons and the control group students who did not take piano lessons were analyzed regarding their age, and it was determined that the short-term visual memory of the experimental group students was better than the control group. The research is considered significant, as it will contribute to the disciplines dealing with child development, piano teachers and other researchers working on this subject.
\end{abstract}

Keywords: music education, musical memory, piano education, visual memory

\section{Introduction}

At the end of the 19th century, musicians made an effort to play the works by heart to reveal the aesthetic norms while displaying their performance skills in front of the public. This was effective in their development of a good musical memory. Memory refers to the processes of remembering, preserving and reproducing the life experiences of individuals. It is known that the functions of memory are 'encoding', 'storage', 'retrieval' and 'forgetting'. Musical memory is an important part of musical abilities and refers to memorizing a musical work, preserving it permanently and reproducing it most accurately even after a long time. Musical memory begins with 'recognition' and is shaped by 'experience' (Efimova, 2017).

Transmitting information to nerve cells in the brain is 'learning', retrieving the information from where it is located is 'remembering', and memory is acknowledged as a necessary element for storing and retrieving information, which is learning and remembering (Engin, Çalapoğlu, \& Gürbüzoğlu, 2008).

Memory consists of four different subcomponents: sensory/perceptive memory, short-term memory, working memory and long-term memory (Türkoğlu, Çetin, Tanır, \& Karatoprak, 2019), each of which has a different neurological function and structure. These subcomponents are described below.

1) Sensory/Perceptive Memory: It is the first cognitive level of memory, where information is perceived by our sense organs. It is limited to very short-term capacity, such as milliseconds, and performs as a kind of filter (Gül, 2006). It is by means of sensory memory that people instantly identify everything they see, hear, taste, smell and touch.

2) Short-Term Memory: Short-term memory is defined as 'the consequences of initial learning' (Gül, 2006). Its capacity is very limited and it is used to store the information in mind in such a short time that can be measured in seconds.

3) Working Memory: It has a limited capacity and can temporarily encode and store stimuli and information in the process of performing cognitive functions and transforming them into action during daily lives (Türkoğlu et al., 2019).

4) Long-Term Memory: It quickly stores information about the world. The information stored in this memory affects the perception of the world and what information will be paid attention to in the environment. 
Long-term memory, whose capacity is not yet fully known, gets stronger with 'repetition' (Engin, Çalapoğlu, \& Gürbüzoğlu, 2008).

The supporting effect of music on the development of memory is known. According to Sacks (as cited in Yeşil, 2014) music, with its evocative power and being a means of expression, assists the ability to organize, to follow complex sequences, and to keep large amounts of information in mind.

The process of memorizing a musical piece sets the relevant memory types in motion. It is known that a good musical memory, which is one of the basic elements of instrument training, is an indispensable part of the education process. Each individual's musical memory is unique to that person (Davidova, 2017) and the development of musical memory can be achieved as a result of intense performance repetitions (Efimova, 2017; Nechaeva, 2018). It is known that musical memory has a very complex structure and includes different types of memory. In this context, the types of memory used in learning music and playing instruments have been diversified and named by many scientists.

According to Haydon (1996), auditory memory, visual memory, kinesthetic memory and theoretical memory, which include mental processes such as memorization, are used in learning music and playing instruments. While Nechaeva (2018) states that musical memory types are visual, auditory, motor-muscular and logical memory, Davidova (2017) expresses that musical memory types are auditory, verbal, motor-muscular, visual, emotional and figurative (descriptive) memory. In contrast to Davidova (2017), Chaffin, Logan, Begosh, Cross, and Thaut (2009) define memory types related to musical performance as auditory, motor, visual, emotional, as well as structural and linguistic memory. Kutadgobilik (2019) states that there are four components in the memorization process: visual (photographic), auditory (acoustic), motor (kinetic/fingers) and analytic (intellectual) memory.

Kutadgobilik (2019), Highben and Palmer (2004) state that the use of every memory type would provide a permanent and safe memorization skill. Likewise, Nechaeva (2018) emphasizes that the more memory types children use in the piano learning process, the more successful they will become. As for Gün Duru and Köse (2016) memorizing a piece by analyzing it from various aspects such as ear memorization, eye memorization, hand-arm movement memorization (kinesthetic) for permanent memorization in the music training process is important.

It can be seen above that various researchers have different classifications of memory types. The types of memory used while playing an instrument are discussed in a general framework and explained below as auditory, visual, kinesthetic and theoretical memory.

1) Auditory memory: Auditory memory develops by listening in the course of learning. Hearing is an indispensable part of instrument training. According to Davidova (2017), as auditory memory is one of the first steps of musical memory, regardless of the development of other memory types, it should be developed immediately and continued at all stages of piano training. As well as auditory memory is a memory that is developed quickly and constantly used by those who are especially talented in music; it often works as naturally as breathing in the act of playing.

The auditory memory of musicians has almost always been considered superior in studies asserting the effect of music training or instrument training. Hallam, Cross and Thaut (2011) state that the research shows that musicians' phonological perceptions also improve with the development of their auditory memory, and it provides advantages such as learning a foreign language, keeping the heard words in mind, and listening skills.

2) Kinesthetic memory (Muscle Memory, Motor Memory): It is known that reading music and playing an instrument is a very complex physical-cerebral motor task that requires years of practice (Çuhadar, 2017). Instrument training requires physical work with the instrument. For the whole body to work in coordination, deliberate muscle-building exercises are performed. Over time, memory develops in the used muscles. Finger memory is one of the most widely known types. The feeling of the fingers touching the keys is improved by training them according to assigned finger numbers. Kinesthetic memory is the system that records the physical sensations while playing a piece (Eroğlu, 2010; Özer, 2020). Even though this memory is obtained as a result of the repeated study, it is known as the most dangerous memory type. This is because motor skills alone cannot be relied upon in situations such as momentary distraction, anxiety, and stress during the performance. According to Özer (2020), kinesthetic memory alone is not sufficient in memorization studies. The motor center of the brain cannot decide whether the learned movement is right or wrong, it only records and ensures that the movement takes place.

3) Theoretical Memory (Conceptual Memory): According to Uzunoğlu (2006), memorizing a piece requires 
paying attention to features such as harmonic structure, formal structure, rhythm patterns, note formation, hand-arm and finger movements and breathing places. Since theoretical memory includes knowledge of theory and form, it is generally more developed in students who study music professionally. In that, the development of this memory can happen as a result of a higher level of education.

In his research on learning, German psychologist Ebbinghaus reveals that $75 \%$ and more of what is learned is forgotten within a week, 66\% within a day, and 54\% within an hour (cited in Uzunoğlu, 2006). The effect of the forgetting factor can be reduced by conscious repetition, and from this point of view, theoretical memory is considered the best way to keep something in mind.

4) Visual Memory: Along with the sense of sight, the concept of visual perception steps in at the point of perceiving and making sense of what one sees, while the concept of visual memory enters at the point of storing meaningful data in the brain for later use. Visual perception and visual memory integrate with cognitive processes, in other words, 'thinking' (Korkutal, 2010).

Visual memory is a perceptual ability allowing visual images to remain in memory even when they leave the field of vision and are invisible. According to Nechaeva (2018), 80\% of people use their visual memory while learning. Visual memory, which is generally defined as the ability to remember a picture, is divided into three basic subsystems as iconic memory, long-term visual memory, and short-term visual memory. Short-term visual memory, which is the subject of the research, is a limited type of memory with a capacity of three to four objects for simple stimuli, and one or two objects for complex stimuli (Aydın, 2017).

In piano training, students are given theoretical and practical musical notation training, and playing starts by reading the notes first. While playing the piano, the students need to visualize the places of the notes on the staff and keyboard in their minds without any help. Reading and playing the notes fluently is possible by memorizing the notes and quickly recognizing them. It is thought that visual memory is extremely effective in musical notation and using the keyboard, providing the perception of the notes' places on the staff and the keyboard mapping.

The development of visual memory makes it easier to overcome difficulties in the process of playing. As a matter of fact, 6-week memorization techniques training was given to the second-grade students at a music department in the study of Yücetoker (2016) on Visual Memory-Based Techniques in Piano Education. In the pre-test, there was no difference between the experimental and control group students, but the students with good visual learning became more successful at the end of the process.

The use of two different clefs (treble clef and bass clef) especially in playing the piano requires more concentration on visual stimuli. There is a monophonic melodic structure in instruments that require the use of a single clef. As it will be relatively easier to follow the melody and other visual stimuli in these instruments, it is believed that auditory and visual memory has less difficulty compared to playing the piano. As a matter of fact, in a study conducted by Rickard, Vasquez, Murphy, Gill, and Toukhsati (2010) where 142 children studying in 9 state primary schools participated, the experimental group students were given one hour of intensive strings instruments training (violin and viola) a week in addition to the usual music lessons, while the control group only attended music lessons. At the beginning of the study, necessary tests were performed to determine verbal memory, visual memory and visual perception. At the end of the first and second years, the same tests were performed, the results were recorded and both groups were compared. Ultimately, while no significant difference was found in the visual memory test, it was determined that the experimental group results were higher in the visual perception test.

It is known that playing the piano requires a cognitive process almost as if playing two instruments. The different notes of two clefs, rhythm patterns, nuances and harmonic structures force the performer to focus constantly. The strengthening of memory also reinforces the piano performance by improving the ability to sightread (reading and analyzing the notes of a musical work that has not been played before). However, it is thought that the development of individuals who receive professional instrument training is different from those who receive private instrument lessons. Students studying at a conservatory also take courses such as ear training, theory, solfeggio, voice training, music history, as well as piano training. As a requirement of education, they often attend concerts and exams. Whereas considering the courses taken by the students who receive professional music education, it is thought that the students who take the private piano lessons usually receive an education based on playing an instrument only, and these students have more limited musical literacy because of this situation. Therefore, it is considered that the musical memories of the students who receive private piano lessons will develop in a long time compared to the students who receive professional music education. Hence, Chaffin, Imreh, and Crafword (2005) draw attention to the impact of piano performances of novice and expert musicians on memory in their research. It has been observed that inexperienced musicians focus more on auditory and motor skills while learning or memorizing a piece, while expert musicians refer to more detailed and comprehensive cognitive mind maps. This situation 
reveals that individuals who receive private music lessons create more limited memory maps than those who receive professional music education. In the literature, research on the effects of other areas such as chess education (Aydın, 2017), movement education (Yurdakul, Çamlıyer, Çamlıyer, Karabulut, \& Soytürk, 2012), digital storytelling (Çıral1, 2014), painting education (Korkutal, 2010) on visual memory have been determined and the effect of visual memory on reading music notation and using the keyboard has been a matter of curiosity. In the research, the relationship between playing the piano and visual memory, which enables the perception of the places of the notes on the staff and the map of the keyboard, has been investigated and the research has been formed to reveal the relationship in question in children who received a private piano lesson.

\subsection{Aim of the Research}

In the research, it is aimed to determine the effect of piano education on visual memory and the answers to the following questions were tried to be sought.

1) What are the short-term visual memory pre-test results of the experimental group students who took private piano lessons and the control group students who did not take piano lessons considering their age?

2) What are the short-term visual memory post-test results of the experimental group students who received private piano lessons and the control group students who did not take piano lessons considering their age?

3) Is there a significant difference in the short-term visual memory test results of the experimental and control group students?

\subsection{The Importance of the Study}

Contemporary science supports knowledge sharing by stretching the boundaries between disciplines. In this respect, the research is considered important, as it will contribute to the disciplines about child development, piano educators and other researchers working on this subject.

\subsection{Assumptions}

It has been assumed that all participants in the study answered the Benton Visual Retention Test carefully and that the test was effective in measuring short-term visual memory.

\subsection{Limitations}

The study has been limited to:

1) 36 students who take private piano lessons and 42 students who do not. All the students are between the ages of 8 and 12 and live in Bursa.

2) Practices for the research carried out between February and May in the 2017-2018 academic year.

3) Benton Visual Retention Test and Personal Information Form used to determine students' short-term visual memory.

4) Healthy students without any physical or clinical ailments.

5) Statistical analyses were conducted for the Benton Visual Retention Test.

\section{Method}

\subsection{Model of the Research}

The methodology of the research was carried out with the quantitative research method, one of the scientific research approaches. Quantitative research aims to reach definite and generalizable results by using numeric data (Gürbüz \& Şahin, 2018).

In the research, experimental research design, one of the quantitative research methods, was used to determine the effect of piano education on the short-term visual memory of children aged between 8 and 12. The experimental research design attempts to determine whether a particular procedure affects the outcome. While the researchers make a special intervention to one of the groups while doing this process, they do not attend the other group and evaluate by determining the scores that both groups get at the end (Creswell, 2017).

\subsection{Study Group}

The study group of the research was determined by the purposive sampling technique. Purposive sampling is a non-probability sampling technique and it is judgmental. It is a type of sampling where researchers select subjects with certain characteristics that they think are suitable for the research problem based on their observations (Creswell, 2017).

The study group of the research consists of 78 students between the ages of 8 and 12 . The experimental group 
$(\mathrm{n}=36)$ consist of students who study at various private schools in Bursa/Turkey and started piano training at least one year ago, while the control group $(\mathrm{n}=42)$ consist of students who study at Private Nilüfer Yönder Primary and Secondary Schools in Bursa/Turkey and have no instrument training. Although the practice started with a study group of 110 people, it was completed with 78 students as a result of some participant leavings.

\subsection{Data Collection Tools}

In the study, the Benton Visual Retention Test F Form was used to measure the short-term visual memory of the participants in the study group. Demographic information of the study group was collected with a Personal Information Form.

Benton Visual Retention Test, which is one of the measurement tools in the neuropsychology literature, is performed for individuals over the age of eight to measure short-term memory. The Benton Visual Retention Test was developed by Benton in 1974. Turkish standardization was done by Anastasiadis in 1984. The test can evaluate the state of memory, distinguishing visual memory from visual perception and motor abilities (Aydin, 2017). Benton Visual Retention Test consists of 15 geometric designs. The norms have been determined for children; those with a high score indicate high memory ability, and those with a score of 5 or less than the limit have an intellectual impairment or disability (Gül, 2006). A gender-related difference in scores has not been seen in studies.

The materials required for the individually administered test are the Benton Visual Retention Test, the form in which the answers are recorded, the Personal Information Form and a pen. The duration of the test is determined as approximately 10 minutes. Participants can get a maximum of 15 points from the test by scoring 1 point for each picture they recognize.

\subsection{Data Collection and Analysis}

For the practice, the permissions of the piano students in the experimental group were obtained from their parents, and the permissions of the students in the control group were obtained from the Provincial Directorate of National Education.

A quiet environment was provided for the experimental and control groups during the pre-test and the post-test. Before the tests, the instructions were explained to all participants one by one. In the test consisting of 15 geometric designs, each design was shown to the students for 10 seconds, then the page was turned and the students were asked to choose the picture shown among four similar options. The answers received from the students were recorded in the answer key registration form.

The experimental group took piano lessons for 1 hour a week for 4 months between February and June 2018. As all of the students had a piano at home, it was ensured that they would practice at home. None of the control group students had received instrument training before.

The pre-test and post-test scores of the students in the experimental and control groups from the Benton Visual Retention Test were analyzed. Descriptive statistics for the experimental and control groups were made. To determine the effect of the practice for the experimental and control groups, t-tests and two-way analysis of variance (mixed-design ANOVA) were performed for the pretest and posttest.

\section{Findings}

\subsection{Findings Regarding the First Research Question}

To answer the first research question of the study, the short-term visual memory levels of the students in the experimental and control groups regarding their ages were examined at the end of the pre-test. The students' levels were evaluated according to the Benton Visual Retention Test Score norm table presented in Table 1.

Table 1. Norm table for Benton Visual Retention Test, forms F and G (For children)

\begin{tabular}{cccccccc}
\hline Age & Deficient & Deficiency Limit & Low Average & Average & Above Average & Superior & Very Superior \\
\hline 8 & $0-4$ & 5 & 6 & $7-8$ & 9 & 10 & $11-15$ \\
9 & $0-5$ & 6 & 7 & $8-9$ & 10 & 11 & $12-15$ \\
10 & $0-6$ & 7 & 8 & $9-10$ & 11 & 12 & $13-15$ \\
11 & $0-7$ & 8 & 9 & $10-11$ & 12 & 13 & $14-15$ \\
12 & $0-8$ & 9 & 10 & $11-12$ & 13 & 14 & 15 \\
$13-14$ & $0-9$ & 10 & 11 & 12 & 13 & 14 & 15 \\
\hline
\end{tabular}


In Table 2, the findings regarding the short-term visual memory levels of the experimental group regarding their age in the pre-test are presented.

Table 2. Distribution of short-term visual memory levels of the experimental group by age in the pre-test

\begin{tabular}{cccccccc}
\hline & \multicolumn{5}{c}{ Pre-test - Experimental Group } & \multirow{2}{*}{ Total } \\
\cline { 2 - 6 } & 11.00 & 12.00 & 13.00 & 14.00 & 15.00 & \\
\hline \multirow{4}{*}{ Age } & 2 & 0 & 0 & 0 & 1 & 3 \\
& 9 & 2 & 2 & 4 & 2 & 0 & 10 \\
& 10 & 0 & 2 & 1 & 2 & 1 & 6 \\
& 11 & 0 & 0 & 1 & 3 & 1 & 5 \\
& 12 & 1 & 2 & 5 & 1 & 3 & 12 \\
\hline Total & & 5 & 6 & 8 & 8 & 6 & 36 \\
\hline
\end{tabular}

When the students in the experimental group are analyzed in general, it is possible to evaluate them as average and above. It is seen that the students aged 8 are at the very superior level, the students aged 9, 10 and 11 are at the superior and very superior level, and the students aged 12 are at the average and above levels.

The findings concerning the short-term visual memory levels of the control group regarding their age in the pre-test are given in Table 3.

Table 3. Distribution of short-term visual memory levels of the control group by age in the pre-test

\begin{tabular}{ccccccccccccc}
\hline & & \multicolumn{10}{c}{ Pre-test - Control group } & \multicolumn{1}{c}{ Total } \\
\cline { 2 - 11 } & 6.00 & 7.00 & 8.00 & 9.00 & 10.00 & 11.00 & 12.00 & 13.00 & 14.00 & 15.00 & \\
\hline \multirow{4}{*}{ Age } & 8 & 0 & 1 & 0 & 1 & 0 & 2 & 0 & 0 & 0 & 0 & 4 \\
& 9 & 1 & 0 & 1 & 1 & 0 & 2 & 3 & 1 & 1 & 1 & 11 \\
& 10 & 0 & 0 & 0 & 0 & 1 & 2 & 3 & 0 & 1 & 0 & 7 \\
& 11 & 0 & 0 & 0 & 0 & 2 & 1 & 2 & 1 & 0 & 0 & 6 \\
& 12 & 0 & 0 & 0 & 0 & 4 & 4 & 4 & 1 & 1 & 0 & 14 \\
\hline Total & & 1 & 1 & 1 & 2 & 7 & 11 & 12 & 3 & 3 & 1 & 42 \\
\hline
\end{tabular}

When the levels of all students in the control group are analyzed, it is seen that they start from the deficience limit. It is seen that students aged 8,10 and 11 are average and above, students aged 9 are at or above the deficience limit, and students aged 12 are at low average and above.

\subsection{Findings Regarding the Second Research Question}

The second research question, the short-term visual memory levels of the students in the experimental and control groups, was analyzed regarding their age in the post-test. The findings concerning the post-test short-term visual memory levels of the experimental group students regarding their ages are given in Table 4 .

Table 4. Distribution of short-term visual memory levels of the experimental group by age in the post-test

\begin{tabular}{cccccccc}
\hline & & \multicolumn{5}{c}{ Post-test - Experimental group } & \multirow{2}{*}{ Total } \\
\cline { 2 - 7 } & & 11.00 & 12.00 & 13.00 & 14.00 & 15.00 & \\
\hline \multirow{4}{*}{ Age } & 8 & 0 & 1 & 0 & 1 & 1 & 3 \\
& 9 & 0 & 0 & 3 & 4 & 3 & 10 \\
& 10 & 0 & 0 & 1 & 1 & 4 & 6 \\
& 11 & 0 & 0 & 0 & 1 & 4 & 5 \\
& 12 & 1 & 0 & 2 & 4 & 5 & 12 \\
\hline Total & & 1 & 1 & 6 & 11 & 17 & 36 \\
\hline
\end{tabular}

According to the post-test results of the students in the experimental group, it was concluded that the general score was average or above. It can be seen that all of the students aged 8, 9, 10 and 11 are at a very superior level, and only at the age of 12 , there are average and above-average students as well as very superior ones. 
The findings regarding the post-test, short-term visual memory levels of the control group by age are presented in Table 5.

Table 5. Distribution of short-term visual memory levels of the control group by age in the post-test

\begin{tabular}{ccccccccccc}
\hline & & \multicolumn{8}{c}{ Post-test - Control group } & \multirow{2}{*}{ Total } \\
\cline { 2 - 10 } & 8.00 & 9.00 & 10.00 & 11.00 & 12.00 & 13.00 & 14.00 & 15.00 & \\
\hline \multirow{4}{*}{ Age } & 8 & 1 & 0 & 2 & 0 & 1 & 0 & 0 & 0 & 4 \\
& 9 & 0 & 1 & 0 & 3 & 3 & 2 & 2 & 0 & 11 \\
& 10 & 0 & 0 & 2 & 3 & 1 & 0 & 1 & 0 & 7 \\
& 11 & 1 & 0 & 0 & 0 & 1 & 2 & 1 & 1 & 6 \\
& 12 & 0 & 0 & 0 & 4 & 5 & 4 & 1 & 0 & 14 \\
\hline Total & & 2 & 1 & 4 & 10 & 11 & 8 & 5 & 1 & 42 \\
\hline
\end{tabular}

When the distributions of the control group are analyzed according to the norm table, it can be stated that the students are in the range of deficiency limit and very superior levels. While students aged 8, 9, 10 and 12 are average and above, students aged 11 are at average and above, with one student at the deficiency limit.

\subsection{Findings Regarding the Third Research Question}

The pretest-posttest mean scores of the short-term visual memory of the students in the experimental and control groups participating in the research before and after the practice are given in Table 6.

Table 6. Descriptive statistics on short-term visual memory levels

\begin{tabular}{ccccc}
\hline & Group & $\eta$ & $X$ & $S S$ \\
\hline \multirow{2}{*}{ Pre-test } & Experimental & 36 & 13.11 & 1.28 \\
& Control & 42 & 11.19 & 1.78 \\
\hline \multirow{2}{*}{ Post-test } & Experimental & 36 & 14.17 & 1.00 \\
& Control & 42 & 11.81 & 1.58 \\
\hline
\end{tabular}

While it was observed that the pre-test means score was 13.11 in the experimental group, the mean score in the control group was calculated as 11.19 . The post-test mean score after the practice was 14.17 in the experimental group and 11.81 in the control group.

To answer the third question of the research, whether there is a significant difference between the pre-test scores of the experimental and control groups was analyzed with the independent samples t-test. T-test findings are presented in Table 7 .

Table 7. T-test results of pre-test mean scores according to experimental and control groups

Note. $\mathrm{SD}=76$.

\begin{tabular}{lllllll}
\hline & Group & $\eta$ & $X$ & $S S$ & $t$ & Pretest \\
\hline \multirow{2}{*}{ Pre-test } & Experimental group & 36 & 13.11 & 1.28 & \multirow{2}{*}{$5.38^{*}$} & \multirow{2}{*}{.00} \\
& Control group & 42 & 11.19 & 1.78 & & \\
\hline
\end{tabular}

As a result of the independent samples t-test, which was conducted to determine whether there was a difference between the pretest mean scores of the experimental and control groups in short-term visual memory levels before the practice, a significant difference $\left[\mathrm{t}_{(76)}=5.38, \mathrm{p}<.05\right]$ was confirmed between the pre-test mean score of the experimental group $\left(x_{e-p r e}=13.11\right)$ and the pre-test mean score of the control group $\left(x_{c-p r e}=11.19\right)$. It can be said that this difference is at a large level when the effect size $(d=1.23)$ is calculated. In this case, it can be affirmed that the experimental group does not show similarities with the control group.

Likewise, after the practice, whether there was a significant difference between the post-test mean scores of the experimental and control groups was analyzed with the independent samples t-test and is shown in Table 8 . 
Table 8. T-test results of post-test mean scores according to experimental and control groups

\begin{tabular}{ccccccc}
\hline & Group & $\eta$ & $X$ & $S S$ & $t$ & $p$ \\
\hline \multirow{2}{*}{ Post-test } & Experimental group & 36 & 14.17 & 1.00 & & \\
& Control group & 42 & 11.81 & 1.58 & & .00 \\
\hline
\end{tabular}

Note. $\mathrm{SD}=76$.

As a result of the independent samples t-test, a significant difference was found between the post-test mean score of the experimental group $\left(x_{e-p o s t}=14.17\right)$ and the posttest mean score of the control group $\left(x_{c-p o s t}=11.81\right)$. The effect size of this difference $(\mathrm{d}=1.78)$ was calculated as large. In this context, it can be said that the practice had a meaningful effect on students' short-term visual memory levels.

To analyze the difference between the pre-test and post-test scores of the experimental and control groups, a paired samples t-test was performed. The findings that have been revealed as a result of the analysis of the pre-test and post-test mean scores of the experimental group before and after the practice with the paired samples t-test are presented in Table 9.

Table 9. T-test results according to experimental group pre-test and post-test mean scores

\begin{tabular}{cccccccc}
\hline & Test & $H$ & $X$ & $S S$ & $r$ & $t$ & $P$ \\
\hline \multirow{2}{*}{ Experimental group } & Pre-test & 36 & 13.11 & 1.28 & \multirow{2}{*}{$.61^{*}$} & \multirow{2}{*}{$-6.09^{*}$} & \multirow{2}{*}{.00} \\
& Post- test & 36 & 14.17 & 1.00 & & & \\
\hline
\end{tabular}

Note. $\mathrm{SD}=35$.

As a result of the analysis, a statistically significant difference was found between the pre-test mean score of the experimental group before the practice $\left(x_{e-p r e}=13.11\right)$ and the post-test mean score after the practice $\left(x_{e-p o s}=14.17\right)$. According to the calculated effect size $(\mathrm{d}=-.92)$, it can be said that the difference is at a large level. It is seen that the practice made in the experimental group has a significant effect on the students' short-term visual memory levels.

The results of the paired samples t-test, in which the difference between the pre-test and post-test mean scores of the control group who did not receive any practice, were analyzed and are given in Table 10.

Table 10. T-test results according to the pre-test and post-test mean scores of the control group

\begin{tabular}{llllllll}
\hline & Test & $\eta$ & $X$ & $S S$ & $r$ & $t$ & $P$ \\
\hline \multirow{2}{*}{ Control group } & Pre-test & 42 & 11.19 & 1.78 & \multirow{2}{*}{.30} & \multirow{2}{*}{-2.01} & \multirow{2}{*}{.05} \\
& Post- test & 42 & 11.81 & 1.58 & & & \\
\hline
\end{tabular}

Note. $\mathrm{SD}=41$.

In the analyses performed, the difference between the pre-test mean scores of the control group before the practice $\left(x_{c-p r e}=11.19\right)$ and the post-test mean scores after the practice $\left(x_{c-p o s t}=11.81\right)$ was not found to be statistically significant. Accordingly, no difference has been observed in the short-term visual memory levels of the students in the control group who did not receive any practice.

When the mean scores of short-term visual memory levels are analyzed, it is seen that the main effect of the test variable is significant, $F(1,76)=20.47, p=<.05$. Accordingly, when the mean scores of short-term visual memory levels are considered regardless of the group, it shows that the post-test scores $(x=12.90)$ are higher than the pre-test scores $(x=12.08)$.

When the group variable was considered, the main effect was found to be statistically significant, $F(1,76)=60.01$, $p<.05$. This demonstrates that the short-term visual memory scores of the control group $(x=11.50)$ are lower than the scores of the experimental group $(x=13.64)$ when the test variable is ignored.

When the test * group interaction was analyzed, it was not found to be statistically significant, $F(1,76)=1.39, p>$ 0.05 . This demonstrates that the increase in the scores of the experimental group $\left(x_{\text {pre }}=13.11, x_{\text {post }}=14.17\right)$ is not statistically significant compared to the increase in the control group scores $\left(x_{p r e}=11.19, x_{\text {post }}=11.81\right)$. 
Two-Way Mixed analysis of variance (ANOVA) was performed to determine whether being in the group of the practice had a significant effect on test scores. Findings related to the analysis are given in Table 11.

Table 11. Two-Way Mixed analysis of variance (ANOVA) results of the practice

\begin{tabular}{cccccc}
\hline & Sum of Squares & $S d$ & Mean Square & $F$ & $p$ \\
\hline Within the groups & & & & & \\
\hline Test & 27.18 & 1 & 27.18 & $20.47^{*}$ & .00 \\
Test * Group & 1.85 & 1 & 1.85 & 1.39 & .24 \\
Error & 100.90 & 76 & 1.33 & & \\
Between the groups & & & & & \\
Intercept & 24500.75 & 1 & 24500.75 & 8290.18 & .00 \\
Group & 177.36 & 1 & 177.36 & $60.01 *$ & .00 \\
Error & 224.61 & 76 & 2.96 & & \\
\hline
\end{tabular}

\section{Discussion}

In the study, the effect of piano education on short-term visual memory skills of children aged 8-12 was analyzed. The first research question of the study was about the pre-test comparison of the short-term visual memory test of the experimental and control group students. When the students in the experimental group are analyzed in general, it is possible to evaluate the visual memory levels of the students as average and above. It is seen that the students aged 8 are at the very superior level, the students aged 9,10 and 11 are at the superior and very superior levels, and the students aged 12 are at the average and above levels. When the levels of all the students in the control group are analyzed, it is observed that they start from the deficiency limit. It is seen that students aged 8, 10 and 11 are average and above, students aged 9 are at or above the deficiency limit, and students aged 12 are at low average and above.

When the findings were analyzed, it can be seen that the pre-test scores of the experimental group are higher than the control group. While the pre-test mean score was observed to be 13.11 in the experimental group, the mean score in the control group was calculated as 11.19. The reason for this difference can be explained with the experimental group students having started playing the piano before the pre-test.

The second research question of the study was about the short-term visual memory test post-test comparison of the experimental and control groups. According to the post-test results of the students in the experimental group, it was concluded that the general was above average. It is seen that all of the students aged 8, 9, 10 and 11 are at a very superior level, and there are only at the age of 12, there are average and above-average students as well as very superior ones. When the distribution of the control group is analyzed according to the norm table, it is observed that the students are usually in the range of deficiency limit and very superior levels. While students aged $8,9,10$ and 12 are average and above, students aged 11 are at average and above, with one student at the deficiency limit. The findings demonstrate that the post-test scores of the experimental group are higher than those of the control group.

According to Gül (2006), children show an increasing development after the age of 8 and reach the highest score when they are at the age of 13-14 in the Benton Visual Retention Test. In the literature, it is stated that scores increase with age after 8 years of age in general. However, $8,9,10,11$ years old children of the experimental group students got high scores from the test in this study. The control group students, on the other hand, generally scored at a superior level.

In the last research question of the study, the difference between the short-term visual memory scores of the experimental and control group students was emphasized. To do that, the mean scores between the pre-test and post-test of both groups were analyzed at first. While there was a statistically significant difference between the pre-test mean scores of the experimental group before the practice and the post-test mean scores after the practice, the difference between the pre-test mean scores of the control group before the practice and the post-test mean scores after the practice was not found to be statistically significant. It was determined that there was no similarity between the experimental and control groups.

When the mean scores of short-term visual memory levels are considered regardless of the groups, it is observed that the post-test scores are higher than the pre-test scores. It was determined that the short-term visual memory scores of the control group were lower than the scores of the experimental group. It shows that the increase in the scores of the experimental group is not statistically more significant than the increase in the scores of the control 
group.

As a result, it is observed that the short-term visual memory of the experimental group students is better than the control group. This can be attributed to the fact that the experimental group students participating in the research have started playing the piano for at least a year and they have been playing the piano during the process of the practice.

When the studies on this subject are analyzed, it is seen that different results have been obtained regarding the effect of music on visual memory. In a study on verbal and visual memory by Jakobson, Lewycky, Kilgour, and Stoesz (2008), memory scores of musicians and non-musicians were analyzed. It was determined that the musicians had higher verbal and visual memory scores. A similar study was conducted by Ho, Cheung, and Chan (2003) and children who received instrument training and those who did not were compared. However, there was a significant difference in verbal memory of children who played instruments and those who did not, but not in visual memory.

Yeşil (2014) used neuropsychological tests measuring attention and memory in her study investigating the effects of music education on symptoms of attention deficit and working memory. While music education provided improvement in working memory, its effect on visual memory could not be determined. Zafranas (2004) revealed that after giving piano training to 61 kindergarten children for one year, their short-term visual memory improved. Degé, Wehrum, Stark, and Schwarzer (2011) provided 10-year-old children with music and instrument training as part of extended music education at school for 2 years, and positive developments were detected in short-term visual and auditory memory of the students.

Ayata and Aşkın (2008) applied neuropsychological tests and neuroimaging techniques to individuals who received or did not receive music training to analyze the effect of music on the brain's cognitive functions. There was a significant difference in favor of musicians regarding attention, concentration and short-term memory between those who started music training under the age of 7 and those who did not receive music training. However, when those who started music over the age of 7 are also taken into consideration, this difference disappeared. It has been determined that the areas of combining images during vision are active in the brains of musicians. It has been emphasized that the reason for this can be that "when the musicians see the musical notation, especially in the first reading process, they have to perceive the notes, rhythm and sounds and transfer all these into finger movements instantly".

\section{Suggestions}

The results of studies about the effects of instrument training on visual memory show differences. This may be because of differences in cultural or educational approaches. Changes in the performance of the subjects, the size of the samples, and the methods applied may also affect these results. It is thought that further research on the subject will produce more consistent results. In this respect:

1) Studies that can measure and compare the visual memory of students playing different instruments can be conducted.

2) The visual memory of children who receive professional music education can be studied.

3) A similar study could be planned for a larger study group and longer duration.

4) Visual memory development can be analyzed after more intensive instrument training (more than 1 hour per week).

\section{References}

Ayata, E., \& Aşkın, C. (2009). Müziğin beynin bilişsel fonksiyonlarına olan etkisi. İtü Dergisi/b, 5(2), 13-22.

Aydın, H. K. (2017). Satrancın çocukların planlama ve görsel-mekansal becerilerine etkileri (Unpublished master's thesis). Uludağ University, Bursa, Turkey.

Chaffin, R., Imreh, G., \& Crawford, M. (2005). Practicing perfection: Memory and piano performance. Psychology Press. https://doi.org/10.4324/9781410612373

Chaffin, R., Logan, T. R., Begosh, K. T., Cross, I., \& Thaut, M. (2009). Performing from memory. The Oxford handbook of music psychology, 352-363.

Creswell, J. W. (2017). Eğitim Araştırmaları: Nicel ve Nitel Araştırmanın Planlanması, Yürütülmesi ve Değerlendirilmesi, (Çev: Ekşi, H \& diğerleri), Edam Yayınları, İstanbul.

Çıralı, H. (2014). Dijital hikâye anlatımının görsel bellek ve yazma becerisi üzerine etkisi. (Unpublished master's thesis). Hacettepe University, Ankara, Turkey. 
Çuhadar, C. H. (2017). Müziksel zekâ. Çukurova Üniversitesi Sosyal Bilimler Enstitüsü Dergisi, 26(3), 1-12.

Davıdova, İ. А. (2017). Музыкальная память и её виды. Методическое сообщение. Moskova.

Degé, F., Wehrum, S., Stark, R., \& Schwarzer, G. (2011). The influence of two years of school music training in secondary school on visual and auditory memory. European Journal of Developmental Psychology, 8(5), 608-623. https://doi.org/10.1080/17405629.2011.590668

Efimova, E. V. (2017). Музыкальная память. Виды музыкальной памяти. Приемы развития музыкальной памяти. Проблемы педагогики, 8(31), 31-34.

Engin, A. O., Calapoğlu, M., \& Gürbüzoğlu, S. (2008). Uzun süreli bellek ve öğrenme. Sosyal Bilimler Enstitüsü Dergisi, 2, 251-262

Eroğlu, Ö. (2010). Müzik Eğitimi Anabilim Dalı Öğrencilerinin Piyano Eserlerini Ezbere Çalma Başarılarında Analitik Ezberleme Yaklaşımının Etkililiği (Unpublished doctoral dissertation). Gazi University, Ankara, Turkey.

Gül, D. (2006). Somut işlem döneminde olan 8-9 yaş çocuklart ile soyut işlem döneminde olan 12-13 yaş çocukların görsel bellek farklllıklarının incelenmesi (Unpublished master's thesis). Maltepe University, Istanbul, Turkey

Gün Duru, E., \& Köse, H. S. (2016). Müziksel ezber üzerine nitel bir çalışma. The Journal of Academic Social Science Studies, 43, 121-131. https://doi.org/10.9761/JASSS3313

Gürbüz, S., \& Şahin, F. (2014). Sosyal bilimlerde araştırma yöntemleri. Ankara: Seçkin Yayıncılık, 271.

Hallam, S., Cross, I., \& Thaut, M. (Eds.). (2011). Oxford handbook of music psychology. Oxford University Press.

Haydon, G. (1996). İnternalization via Memorization for the Intermediate Student. In J. Lyke, Y. Enoch, \& G. Haydon (Eds.), Creative Piano Teaching (3rd ed., pp. 340-347). Champaign, Illinois: Stipes Publishing.

Highben, Z., \& Palmer, C. (2004). Effects of auditory and motor mental practice in memorized piano performance. Bulletin of the Council for Research in Music Education, 58-65.

Ho, Y. C., Cheung, M. C., \& Chan, A. S. (2003). Music training improves verbal but not visual memory: Cross-sectional and longitudinal explorations in children. Neuropsychology, 17(3), 439. https://doi.org/10.1037/0894-4105.17.3.439

Jakobson, L. S., Lewycky, S. T., Kilgour, A. R., \& Stoesz, B. M. (2008). Memory for verbal and visual material in highly trained musicians. Music Perception, 26(1), 41-55. https://doi.org/10.1525/mp.2008.26.1.41

Korkutal, P. (2010). Resim-iş eğitimi anabilim dallarında görsel belleğin gelişimine yönelik öğretim etkinlikleri ile görsel algu ilişsileri (Unpublished doctoral dissertation). Dokuz Eylül University, Izmir, Turkey.

Kutadgobilik, S. (2019). Klasik Batı Müziği icrasında literatür açısından ezber olgusu. Konservatoryum, 6(1), 91-103. https://doi.org/10.26650/CONS2018-0013

Nechaeva, L. İ. (2018). Игра наизусть Эффективные методы развития памяти в процессе обучения игре на фортепиано. Методическая разработка, Красная поляна.

Özer, B. (2020). Piyano eğitiminde zihinsel çalışma ve ezberlemenin önemi. Eğitim Bilimleri: Teori, Güncel Araştırmalar ve Yeni Eğilimler. İvpe.

Özyürek, A., \& Ömeroğlu, E. (2013). Bellek eğitimi programının altı yaşındaki çocukların bellek gelişimine etkisinin incelenmesi. Ĕgitim ve bilim, 38(168), 30-45.

Rickard, N. S., Vasquez, J. T., Murphy, F., Gill, A., \& Toukhsati, S. R. (2010). Benefits of a classroom-based instrumental music program on verbal memory of primary school children: a longitudinal study. Australian Journal of Music Education, 1, 36-47.

Roden, I., Grube, D., Bongard, S., \& Kreutz, G. (2014). Does music training enhance working memory performance? Findings from a quasi-experimental longitudinal study. Psychology of Music, 42(2), 284-298. https://doi.org/10.1177/0305735612471239

Türkoğlu, S., Çetin, F. H., Tanır, Y., \& Karatoprak, S. (2019). Çalışma belleği ve nörogelişimsel hastalıklar. $\begin{array}{llllll}\text { Çocuk ve Gençlik Ruh Sağlığl Dergisi, } & \text { 26(2), }\end{array}$ https://doi.org/10.4274/tjcamh.galenos.2019.2018.11.034

Uzunoğlu, B. (2006). Müzik Öğretmeni Yetiştiren Kurumlarda Ezber Çalmanın-Söylemenin Öğrenci Başarısına 
Etkisinin Değerlendirilmesi (Unpublished master's thesis). Uludağ Univesity, Bursa, Turkey.

Yeşil, B. (2014). Müzik lisans eğitiminin dikkat eksikliği belirtileri ve çalışma belleği üzerine etkileri (Unpublished doctoral dissertation). İnönü Univesity, Malatya, Turkey.

Yurdakul, N. A., Çamlıyer, H., Çamlıyer, H., Karabulut, N., \& Soytürk, M. (2012). Sekiz yaş grubu çocuklarda hareket eğitiminin dikkat ve hafiza gelişimine etkileri. Selçuk Üniversitesi Beden Eğitimi ve Spor Bilimleri Dergisi, 14(1), 103-108.

Yücetoker, I. (2016). The visual memory-based memorization techniques in piano education. Eurasian Journal of Educational Research, 16(65), 111-128. https://doi.org/10.14689/ejer.2016.65.07

Zafranas, N. (2004). Piano keyboard training and the spatial-temporal development of young children attending kindergarten classes in Greece. Early Child Development and Care, 174(2), 199-211. https://doi.org/10.1080/0300443032000153534

\section{Copyrights}

Copyright for this article is retained by the author(s), with first publication rights granted to the journal.

This is an open-access article distributed under the terms and conditions of the Creative Commons Attribution license (http://creativecommons.org/licenses/by/4.0/). 